\title{
Assessing And Analysing Students' Vocabulary Understanding Through 6 Kinds Of Tasks
}

\author{
Uswatunnisa Usman \\ Diponegoro University \\ Semarang, Indonesia \\ nyd.nisa@gmail.com
}

\begin{abstract}
Vocabulary is a language element, which plays an important role. A student cannot master English well if they do not master vocabulary and have a good vocabulary understanding. This study is a mixed method study. It aims to assess and analyze students' vocabulary understanding by using six kinds of tasks. The total sample is 20 students of class XI (Tata Busana Program) in Vocational School 1 Limboro. The researcher used two instruments, those are vocabulary test and questionnair. The results show there are only two students who have fair and good vocabulary understanding, 10 students are in poor category, and 6 students are in very poor category. The highest score is 75 and the lowest one is 5 . Most students are failed in verb, but the students master noun the most. Most students chose task 1 (matching words and the meaning) and task 5 (finding the word class) as the easier tasks and task 2 (finding synonym and antonym) as the most difficult one. In conclusion, the students need a new treatment from teacher in order to enrich their vocabulary understanding.
\end{abstract}

Keywords-Vocabulary understanding, vocabulary test, assessment.

\section{INTRODUCTION}

Vocabulary is the key of four language skills, those are reading, speaking, listening, and writing. According to [1] vocabulary is a content and function words language which are learned so thoroughly, that they become a part of the child's understanding, speaking, and later reading, and writing. In reading text students need vocabulary mastery to understand the text. In conducting a conversation or discussion students need vocabulary mastery to speak fluently. Also in listening students need vocabulary mastery to understand what the topic about. Then, in writing students also need vocabulary mastery in order to be able to express the ideas easily. It proves that vocabulary is crucial for mastering English. Thus, by mastering vocabulary students will be facilitated for mastering four language skills.

[2] In her book "Assessing Vocabulary in the Language Classroom" explained important points for teacher or researcher in assessing vocabulary. She provided explanations about kinds of tasks in vocabulary testing and how to assess vocabulary. She stated that assessing vocabulary should have the same priority as other skills in that the important cornerstones of testing (validity, reliability, practicality, washback, authenticity, transparency and security) need to be considered in designing and evaluating tests of lexical knowledge and use. Furthermore, she shows some samples of vocabulary task.

Some students who learn English still have poor vocabulary understanding, especially students in a small town such as Vocational School Limboro which has different treatment in learning English from a big city. The researcher assumes that the less understanding of vocabulary is one of reasons why the students in that school have poor English mastery. There are some students who know the definition of the words only but do not understand the whole part of the words that matters, such as the word class (part of speech), the meaning, and so on. By having a good vocabulary understanding students will be able to master all language skills easily.

Based on the research problem above, the researcher formulate some research questions as follows:

1. How is students vocabulary understanding?

2. What P.O.S that students failed the most?

3. Which one is the most difficult task for students? And which one is easy?

This research aims to assess and analyze students vocabulary understanding. The researcher will find the results by giving the vocabulary tests to the students then assess it. The researcher will find the result of students vocabulary understanding and the P.O.S students failed the most through the result score of the tests. Then, the researcher will provide the students questionnair to find the answer of which task that the most difficult, easy, and good according to them.

Theoretically, this research is expected to give contribution and provide the explanation about students vocabulary understanding. Practically, the results of this research are expected to show the students the results of their vocabulary understanding and to show the teacher which kinds of vocabulary tasks the students good at and failed the most.

Studies related to this research are [3] in her study "Enriching the Students' Vocabulary through Personal Vocabulary Notes" used a classroom action research method at SMP Unismuh Muhammadiyah Makassar. Based on the result of this study, it showed that there was a significant difference between cycle 1 and cycle 2 , in which the mean scores increased from $67.05 \%$ to $85.90 \%$. 


\section{RESEARCH METHOD}

In this part the researcher is going to explain about the method of the research and how to assess students' paperwork.

This research applies mixed-method research design. The researcher provides vocabulary tests and questionnair for 20 students in class XI (Jurusan Tata Busana) Vocational School Limboro. There are six kinds of tasks in the vocabulary test, those are matching the words with their meaning is related with word meaning ; finding synonym and antonym are related with additional new vocabulary ; making sentences is related with word use and word grammar ; filling the blank spaces is related with word use and word grammar ; finding the word class and word formation are related with word class and word formation ; completing the blank spaces with different kinds of words formation is related with word formation and word use and word grammar.

There are 10 numbers for each task, so the total number is 60 numbers. Each answer scored based on scoring requirements as follows:

1. Add 1 point for correct answer.

2. Give 0 point for each incorrect answer.

Then, considering those tasks the researcher analyzed the data by using the following terms:

1. The following formula is used to score the student's correct answer at the vocabulary test:

Students correct answer score

$$
\text { Score }=\frac{\text { The total number of items }}{\text { X } 100}
$$
(DEPDIKNAS, 2006)

2. The following categories were used to classify the students score:

The classification score

\begin{tabular}{|l|c|c|}
\hline No & Mastery Level & Category \\
\hline 1. & $86-100$ & Very Good \\
\hline 2. & $71-85$ & Good \\
\hline 3. & $56-70$ & Fair \\
\hline 4. & $41-55$ & Poor \\
\hline 5. & $<40$ & Very Poor \\
\hline
\end{tabular}

\section{FINDINGS AND DISCUSSION}

As this research used two different instruments, vocabulary test and questionnair, so there will be two explanations part which is related and support each other.
A. Vocabulary Test

The results of vocabulary test shows that the vocabulary understanding of most students in Vocational School Limboro is poor. The following table shows the students' result score :

\begin{tabular}{|c|c|c|c|}
\hline NO & NAME & SCORE & CATEGORY \\
\hline 1 & Ela Purwati & 75 & GOOD \\
\hline 2 & Rahmawati & 71.5 & GOOD \\
\hline 3 & Nisma Anisa & 64 & FAIR \\
\hline 4 & Nur Alma & 59 & FAIR \\
\hline 5 & Herna & 55 & POOR \\
\hline 6 & Suri Anti & 51.5 & POOR \\
\hline 7 & Sukmawati & 49 & POOR \\
\hline 8 & Ella Dinni & 49 & POOR \\
\hline 9 & Nur Syam & 49 & POOR \\
\hline 10 & Zulfitri & 48.5 & POOR \\
\hline 11 & Dartiana & 47 & POOR \\
\hline 12 & Herni & 47 & POOR \\
\hline 13 & Masriati N. & 44 & POOR \\
\hline 14 & Salma & 42 & POOR \\
\hline 15 & St. Aminah & 38 & VERY POOR \\
\hline 16 & Rahmatiah & 34 & VERY POOR \\
\hline 17 & Hasan & 21 & VERY POOR \\
\hline 18 & Ramli & 17 & VERY POOR \\
\hline 19 & M. Syamar & 16 & VERY POOR \\
\hline 20 & Arnita & 5 & VERY POOR \\
\hline
\end{tabular}

\begin{tabular}{|l|l|}
\hline \multicolumn{1}{|c|}{ Vocabulary Understanding Category } & Total Students \\
\hline GOOD & 2 students \\
\hline FAIR & 2 students \\
\hline POOR & 10 students \\
\hline VERY POOR & 6 students \\
\hline
\end{tabular}

Based on those results the researcher concludes that most students are failed in vocabulary understanding test. There are only 2 students who are in fair and good category, 10 students are in poor category, and another 6 students are in very poor category. It also means that students' English competence are still poor. The students clearly need a special treatment to help them enhancing their English mastery and to enrich their vocabulary understanding.

Based on the students' paper-work, most students are failed in task $2,3,4$, and 6 . It means that students are failed in word use, word grammar, and word formation. As we know in vocabulary learning students are expected to know about how to use a word correctly whether in oral or written. Besides, students should know about the grammar, structures, tenses, and so on. Students are also should know about the word formation. It is about a word could possibly has different word class in different formation, such as 'Excite, Excitement, Excited'.

Students who failed in task 2 in finding synonym and antonym of the words means they are lack of vocabulary mastery. Here are the ten given words in this vocabulary test:
1. Woodcutter
6. Able
2. Thieves
3. Tremble
4. Excitement
7. Disguise
8. Poor
9. Pour
5. Wondrous
10. Stab 
Most students do not know the synonym and antonym of 'wondrous, stab, disguise, and even for such very basic words for Senior High School level like thieves, excitement, able, and poor. For example the word 'thieves', most students wrote 'took or take' for the synonym rather than 'burglar or stealer' and 'give' for the antonym rather than 'giver'. It shows that students have low vocabulary mastery. They do not understand well that for some words a verb cannot be the synonym or antonym af a noun.

In task 3 students have difficulty in making sentences. They even do not know how to make a simple yet correct sentence. Sentences they made were grammatically uncorrect, means their sentences express different meaning. The tenses they used were uncorrect. Students do not understand well enough about tenses even for a very basic one, such as simple present tense, simple past tense, and continuous tense. Here are some sentences students made in task 3:

- My father woodcutter - My handphone is tremble

- I am very excitement - He is disguise every night

- He is stab me - I'm is a poor

- Alibaba a stab - My friends thieves

- They are pour water - Ticher is a wondrous

(Italic words are the given words)

Referrring to those sentences the researcher simply can concludes that most students know the definition of the words only but do not understand well the meaning of the words and how to use them correctly. Most of their sentences are failed in both grammar and tenses. So that the students are failed in word use and word grammar understanding.

Most students are also failed in task 4 and 6. Task 4 and 6 are actually similar. Both of them are about to fill the blank spaces using the given words. But the differences are, task 4 is in sentences form and task 6 is in paragraph form. Besides, in task 4 the students are asked to fill the blank spaces using the ten given words. But in task 6 the students are provided another ten word formations from different POS. They are failed in those tasks because their vocabulary mastery and vocabulary understanding are poor. They could not distinguish each word formation. For example in task 6, some students' answer:

- ...I am too excitement today....

- .....This excited me......

Most students are succeed in task 1 and task 5 . Task 1 is about matching the words with the meaning written in English and task 5 is about finding the word class. It means that, most students has no difficulty with the word meaning as long as they know the Indonesian meaning. The results also prove that the students has no difficulty in finding the word class as long as they know the Indonesian meaning of each word.
Students are failed in verb the most. It is proved by the students' paper work. From all six kinds of tasks, students got difficulties in understanding and using verb than other part of speech. Especially when they were asked to make sentences using verbs, the sentences were uncorrect. They still do not understand well enough about regular and irregular verb.

\section{B. Questionnair}

The questionnair contains 10 questions (see appendix). The questions are about English and vocabulary. The researcher was intended to know whether or not the students were interested in English and so on. The results are as follows :

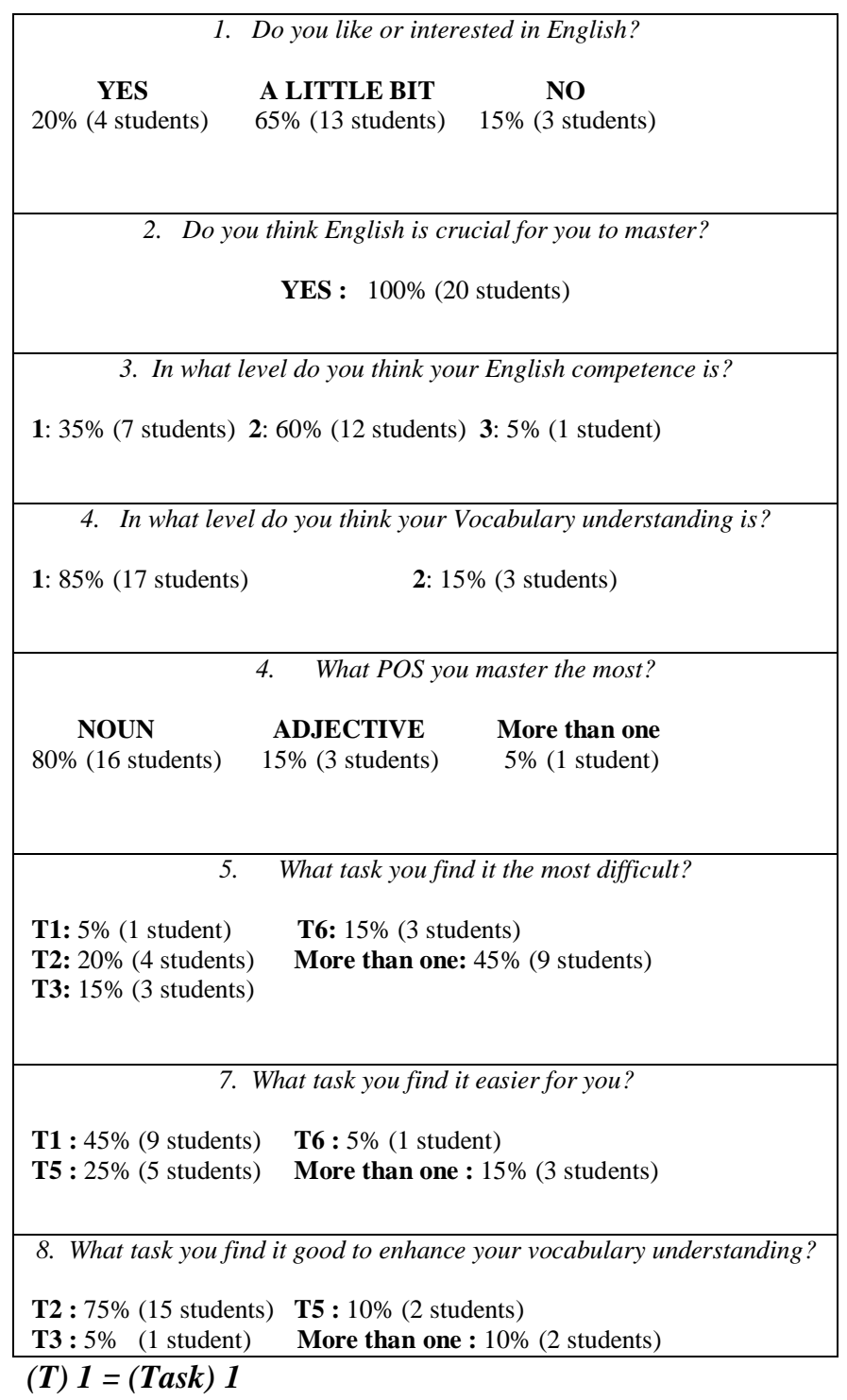

Each question supports the findings of this research. There are only 4 students who are interested in English, though all of them agree that English is crucial. Most students are also consider themself have poor English competence and very poor vocabulary understanding. There 
are $80 \%$ students consider themself master noun the most rather than the other part of speech, such as verb and adjective. But there were also some students who did not answer certain questions in the questionnair.

There are $75 \%$ students choose T2 (see appendix) as a good task to enhance their vocabulary understanding. Their reason is because T2 provide them more new vocabulary. Most of the students are also said that these tasks (vocabulary test) are useful for them in order to know to what extent their vocabulary understanding is. Based on the result of this questionnair, difficult task is more than one. Then, the easier task is Task 1 , it is about finding the meaning or definition of the words.

\section{CONCLUSION}

To sum up all the findings of this research, the researcher finally come up with the conclusion that students in class XI Tata Busana Program in Vocational School 1 Limboro are lack in vocabulary understanding. Most of the students are failed in verb. The highest score of the vocabulary test is 75 . It proves that the students really need a kind of new but useful method in learning English so that they will be more facilitated in mastering and understanding vocabulary. By mastering and understanding vocabulary the students will be more easier in mastering English. The findings of this research could be an approach for both the students and the teacher to be more aware in enhancing students' English competence.

\section{REFERENCES}

[1] Brown, H. Douglas. 2006. Principles of Language Learning and Teaching $5^{\text {th }}$ Edition. New York: Pearson/Longman.

[2] Coombe, Christine. 2013. Assessing Vocabulary in Language Classroom. Kuala Lumpur: Malaysian English Language Teaching Association.

[3] Rasyid, Fatmawati. 2011. Enriching the Students' Vocabulary through Personal Vocabulary Notes. Thesis S1. University of Muhammadiyah Makassar (unpublished).

[4] Depdiknas. 2006. Kurikulum Berbasis Kompetensi. Jakarta: Departemen Pendidikan Nasional. 